\title{
ZAKOUŠENÍ BOLESTI PODLE ARISTOTELA
}

\author{
Vojtěch Linka
}

\section{Úvod}

Slast a bolest zaujímají v Aristotelově etice významné místo. V Politice čteme, že k přirozenosti živočichů patří zakoušet slast a bolest. ${ }^{1}$ Pokud se zaměříme přímo na člověka, je toto tvrzení dále rozvinuto: slasti a bolesti jsou trvalým rysem náležejícím k lidskému chování, což se ukazuje zejména na rovině etických ctností a emocí. ${ }^{2}$ Při bližším pohledu však zjišt'ujeme, že v dochovaných textech přichází jedna polovina problému slasti a bolesti poněkud zkrátka. Zatímco o slasti pojednává Aristotelés poměrně podrobně, tedy zkoumá význam a funkci slasti pro dobrý život člověka, vyrovnává se s názory ostatních myslitelů atd., o bolesti se dozvídáme velmi málo. I v případě Etiky Nikomachovy se jedná o několik velmi krátkých pasáží. ${ }^{3}$ A tak třebaže Aristotelés přiznává bolesti důležité místo ve svém etickém systému, její přesný výměr a charakteristiku, zdá se, nepodává.

Tento trend je patrný také u myslitelů, kteří se zabývají Aristotelovou etikou. Jak v antice, tak mezi současnými autory se pojednává převážně o slasti. ${ }^{4}$ Pokud ovšem hraje bolest v Aristotelově etice tak velikou roli,

\footnotetext{
1 Aristotelés, Pol. I,2,1253a9-15.

2 Týž, Eth. Nic. II,3,1104b26-8; 1105a1-9; III,6,1106b14-23.

3 Konkrétní pasáže jsou citovány níže. Souhrnně ke slasti a bolesti viz zejména, VII,12-14; X,2-4.

4 Wei Cheng si všímá, že v antice to byl jen Alexandr z Afrodisiady, kdo se zabýval bolestí u Aristotela. Viz W. Cheng, Alexander of Aphrodisias on Pleasure and Pain in Aristotle, in: W. Harris (vyd.), Pain and Pleasure in Classical Times, Leiden 2018, str. 174-201. Mezi současnými badateli byla doposud výrazně větší pozornost věnována právě slasti. Viz např. D. Frede, Pleasure and Pain in Aristotle's Ethics, in: R. Kraut (vyd.), The Blackwell Guide to Aristotle's Nicomachean Ethics, Oxford 2016, str. 255-276; C. C. W. Taylor, Pleasure: Aristotle's Response
} 
jak on sám naznačuje, může jednostranné zaměřování se na slast vést ke zkreslení. Toho si byl vědom Wei Cheng, který se ve své disertaci věnoval podrobně jak slasti, tak bolesti. Jeho detailní analýza ukázala, že Aristotelovu teorii bolesti je možné rekonstruovat. ${ }^{5}$

Cheng vychází z premisy, že díky vztahu pojmů slast a bolest je možné při výkladu jednoho z nich přihlížet k výkladu toho druhého. A jelikož Aristotelés rozvíjí explicitně teorii slasti, je možné tuto teorii použít př́i zkoumání bolesti. Cheng tento postup nazývá zrcadlovou metodou a také my se ho budeme držet. ${ }^{6}$

Přístup k tématu bolesti, který budeme hájit v tomto článku, do určité míry odpovídá př́ístupu Chengovu. I my se budeme snažit nalézt jednotný koncept, který Aristotelés používá pro popis různých typů bolesti. Při hledání tohoto konceptu se stejně jako on domníváme, že bolest je možné vysvětlovat pomocí pojmu xívๆoıs, nebo pomocí pojmu maření évé $Q \gamma \varepsilon \iota \alpha .^{7}$ Naše postupy se liší v tom, který z těchto modelů vidíme při rekonstrukci Aristotelovy teorie bolesti jako primární. Zatímco Cheng chápe bolest především jako xívๆoıs, my ji chápeme

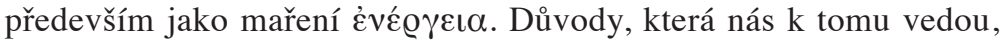
představíme níže. Nejprve však musíme začít problémem slasti a jejího vztahu k bolesti.

\section{Slast v Etice Nikomachově}

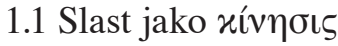

Rozboru slasti jsou věnovány poslední kapitoly VII. knihy a první kapitoly X. knihy Etiky Nikomachovy. Nejdříve se zaměříme na několik míst týkajících se slasti v VII. knize a celkový obraz doplníme o klíčová místa v knize X. V průběhu tohoto oddílu již budeme brát zřetel na ty aspekty slasti, které by mohly hrát nějakou roli v pochopení bolesti.

to Plato, in: týž, Pleasure, Mind, and Soul. Selected Papers in Ancient Philosophy, Oxford 2008, str. 240-265; D. Wolfsdorf, Pleasure in Ancient Greek Philosophy, Cambridge 2013.

5 Viz W. Cheng, Pleasure and Pain in Context. Aristotle's Dialogue with His Predecessors and Contemporaries, Ph.D. diss., Humboldt-Universität zu Berlin, 2015.

6 Viz tamt., str. 336.

7 Viz tamt., str. 362-370. 
Abychom pochopili místo a funkci bolesti a slasti v Aristotelově etické teorii, je dobré připomenout si následující:

„Za známku toho či onoho habitu je pak třeba považovat slast či bolest přistupující k tomu, co konáme. Kdo se zdržuje tělesných slastí a má z toho radost, je uměřený, kdo se pro to mrzí, je naopak bezuzdný. Dokáže-li někdo s radostí či alespoň bez toho, aby se trápil, snášet věci, které jsou strašné, je statečný, trápí-li se, je zbabělec. Mravní ctnost je totiž se slastmi a bolestmi svázaná. Nebot' konáme-li něco nízkého, konáme to kvůli slasti, odmítáme-li konat něco krásného, pak kvůli bolesti.“8

Aristotelés argumentuje tak, že kvůli spojení s mravní ctností je třeba věnovat $\mathrm{v}$ etické teorii slasti a bolesti náležitou pozornost. Jak se dozvíme dále, bolest je něco špatného, čemu se lidé vyhýbají, kdežto slast něco dobrého, co následují. ${ }^{9}$ Ale $c o$ je slast? Nejdříve se podívejme na negativní vymezení, vycházející z kontextu diskusí v Akademii. Aristotelés odmítá chápat slast po vzoru Platónova dialogu Filébos jako „pocit’ované vznikání přrirozeného stavu“. ${ }^{10}$ Klíčový je zde tedy pojem

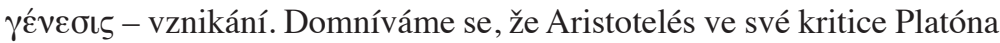
chápe pojem vznikání jako spadající pod širší pojem pohybu - xívๆoıs. Je tomu tak proto, že Aristotelés se v klíčových pasážích, které budeme níže citovat, snaží dokázat, že slast má rysy, které pohybu nenáleží (slast

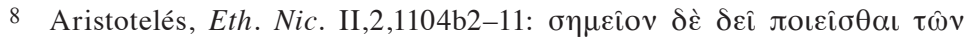

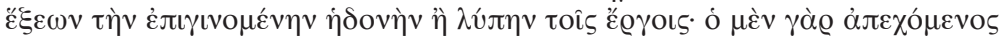

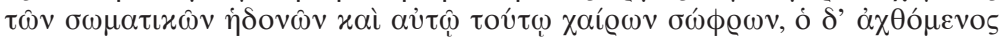

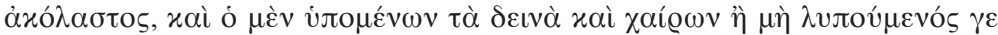

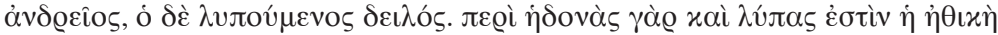

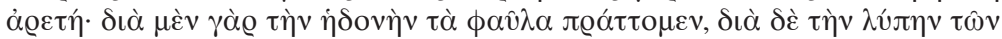

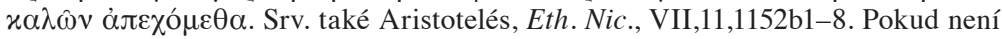
uvedeno jinak, používáme pracovní překlad Etiky Nikomachovy Matyáše Havrdy a Jaroslava Rytîre; za svolení jim velmi děkujeme. Řecký text citujeme podle: Aristotelis Ethica Nicomachea, vyd. I. Bywater, Oxford 1894.

9 Viz Aristotelés, Eth. Nic., VII,11,1153b1-4 a X,2,1173a11-13.

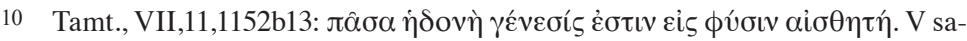
motném Filébovi, k němuž Aristotelův text odkazuje, je ovšem formulace následující: „Sókratés: Zdali jsme neslyšeli o slasti, že jest to vždy děj, kdežto slast jako jsoucno vůbec není?" Platón, Philb. 53c4-5, překlad F. Novotného (srv. orig. text:

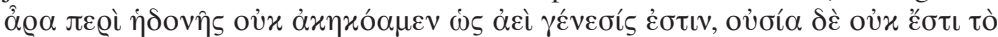

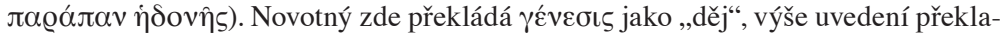
datelé Etiky Nikomachovy jako „vznikání“. 
je dovršená v každém okamžiku, má cíl sama v sobě atd.). Místo pohy-

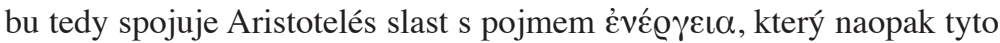
rysy má (viz následující oddíl). Jádrem Aristotelovy kritiky tohoto pojetí je, že půjde o pohyb směrem k přirozenému stavu nebo o ,pocit'ované vznikání "přirozeného stavu, tedy rovněž pohyb či návrat. ${ }^{11} \mathrm{Z}$ takového dynamického chápání vyvozoval Platón své negativní ohodnocení slasti, jako např́íklad v dialogu Gorgias: je-li slast návratem k přirozenému stavu, nemůžeme ji ztotožnit s dobrem. ${ }^{12}$ Slast vždy implikuje předcházející chybění, tak jako slast z jídla je podmíněna předcházejícím hladem. Při pohybu nasycování, a stejně tak u ostatních případů slasti, je proces návratu $\mathrm{k}$ přirozenému stavu spojen s bolestí. Oba tyto fenomény ustanou v okamžiku navrácení se k přirozenému stavu, který ovšem následně není stavem slasti, ale klidu. Na rozdíl od slasti je tento stav dobrý, nebot' není spojen s chyběním a nedostatkem.

Aristotelovi jde o to ukázat, že slast je přítomná i v přirozeném stavu, tedy v těch situacích, kdy se podle Platóna nacházíme v klidu, bez slasti či bolesti. Aby to bylo možné, bude Aristotelés muset upravit výměr slas-

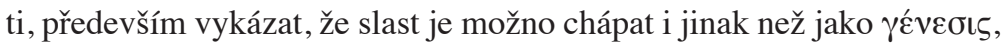
resp. xívๆoıs. ${ }^{13}$

\subsection{Slast jako évé@ $\gamma \varepsilon ı$}

Aristotelés navrhuje odlišný výměr slasti v následující pasáži:

„Dále, není nutné, aby existovalo něco jiného než slast, co je lepší než ona, jak to někteří tvrdí o cíli ve vztahu ke vznikání. Slast není žádné vznikání, ani nejsou všechny slasti se vznikáním spjaty, nýbrž jsou to činnosti a cíl. Navíc to, co provázejí, není vznikání, nýbrž užívání. Ne u všeho je také cílem něco jiného: pouze u toho, co je k cílovému stavu své přirozenosti vedeno. Proto také není správné tvrzení, že

11 Pro hlubší rozbor Platónovy teorie slasti viz např. G. van Riel, Pleasure and the Good Life. Plato, Aristotle, and the Neoplatonists, Leiden 2005.

12 Viz Platón, Gorg. 496c-497d; Philb. 31d-32e. Třebaže bychom mohli jezení a pití chápat jako činnost (ve smyslu prattein), jedná se obecně o proces - návrat k přirozenému stavu, a tedy pohyb. Platón zde nicméně nepoužívá slovo xívๆбıs. To používá až Aristotelés ve své kritice platónského pojetí slasti a bolesti in: Eth. Nic. $\mathrm{X}, 2-4$.

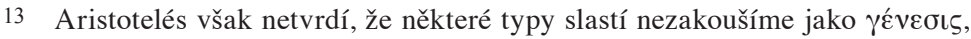

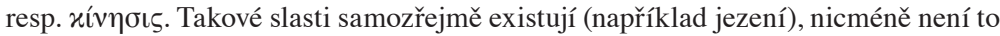
jediný typ slasti. 
slast je pocit'ované vznikání. Spíše řekneme, že je to činnost, v níž se uskutečňuje přirozený habitus, a místo slova ,pocit'ovaná‘ dodáme ,které nic nepřekážíi" “"14

Pohyb nemá cíl sám v sobě, vykazuje tedy jistou nesamostatnost a závislost. Aristotelés nicméně chce rozšírit oblast slasti za tuto hranici i na ty fenomény, které pohyby nejsou. Používá tedy pojmy ėvé a $\tau \hat{\varepsilon} \lambda$ os. Slast, která je na tomto místě s činností ztotožněna, je charakte-

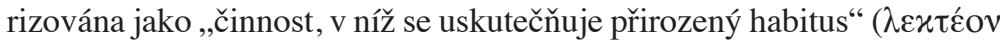

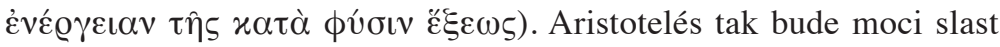

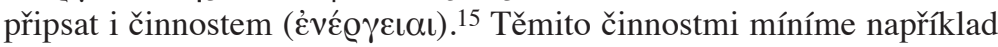
smyslové vnímání nebo myšlení, které mají cíl samy v sobě a jsou úplné v každém okamžiku svého průběhu. ${ }^{16}$

V X. knize Etiky Nikomachovy je blíže pojednán problém vztahu slasti a činnosti. V úryvku ze VII. knihy, jejž jsme citovali výše, se jedná o prosté ztotožnění. Tento názor Aristotelés nicméně dále modifikuje. Dříve než popíše vztah mezi slastí a činností, uvádí několik důvodů, proč se slast musí vázat na činnosti a nikoli na pohyb. Jeden z těchto důvodů je např́íklad ten, že zakoušení slasti neprobíhá rychle nebo po-

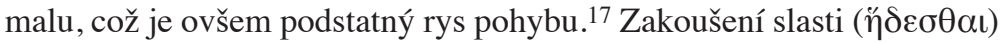
nebude tedy nějaká pomalá či rychlá změna, ale bude to jakési uskuteč-

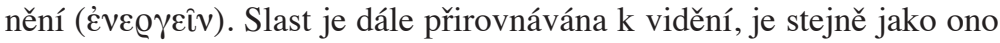
završená v kterémkoli okamžiku: „Není možné nalézt žádný časový úsek

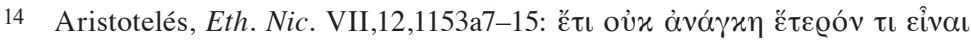

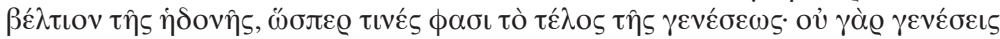

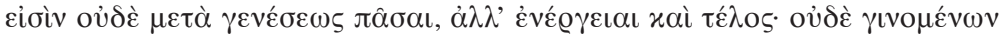

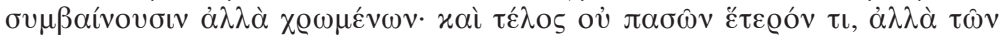

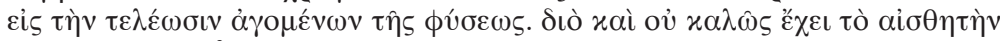

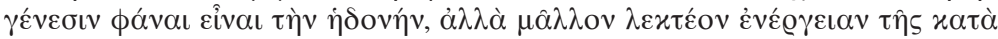

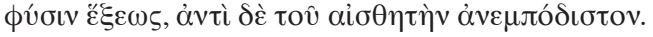

15 Stejně jako překladatelé Etiky Nikomachovy používáme pro évé@ $\gamma \varepsilon ı$ slovo „с̌innost“.

16 Zde se přikláníme $\mathrm{k}$ takovému pojetí smyslového vnímání, kdy při vjemu sice dochází k nějaké změně ve smyslovém orgánu (a tedy v širším smyslu k pohybu), zároveň se ale při smyslovém vnímání jedná o „změnu jiného druhu“ (Aris-

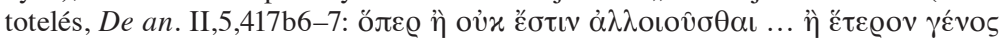

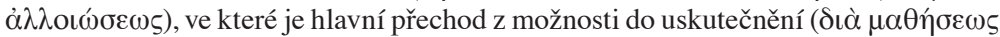

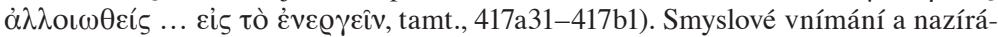
ní se „Vypovídají co do uskutečnění“ (

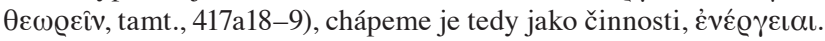

17 Viz Aristotelés, Eth. Nic. X,2,1173b2-4. 
trvání slasti, kdy by slast musela vznikat ještě po další čas, aby byla její forma završená.“18

Dále Aristotelés připisuje každé činnosti její vlastní slast. ${ }^{19}$ Každé činnosti náleží slast, pokud se „dobře má ve vztahu k tomu nejušlechtilejšímu, co pod ni spadá“ ${ }^{20}$ Pokud činnosti nic nebrání a ta se náležitě vztahuje ke svému předmětu, přichází slast. To, že dané činnosti náleží slast, má nejpodstatnější důsledek v tom, že se činnost stane završenou. ${ }^{21}$

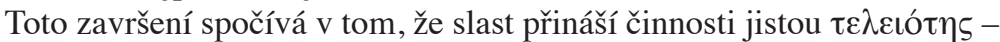
dokonalost. Činnost, jak ji Aristotelés chápe v Etice Nikomachově, je dokonalá v tom smyslu, že na rozdíl od pohybu nemá nějaký vnější cíl, že je završená sama $v$ sobě. ${ }^{22}$ Přesto slast přináší činnosti ještě další dokonalost:

„Slast však tuto činnost nezavršuje stejným způsobem jako habitus, který je v této činnosti obsažen, ale jako jakási přistupující dokonalost, tak jako půvab přistupuje k lidem, kteří jsou v rozpuku sil." 23

Tato pasáž je předmětem zájmu moderních komentátorů. Sarah Bro-

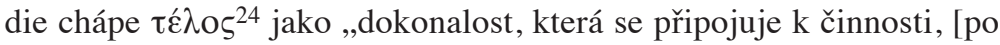
připojení] je však od ní neoddělitelná“. ${ }^{25}$ Gerd Van Riel překládá c̋@ $\alpha$ (půvab) jako „bloom“, který se dostavuje v situaci, kdy člověk dosáhl

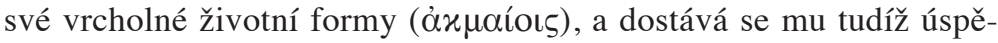

18 Aristotelés, Eth. Nic., X,3,1174a14-19.

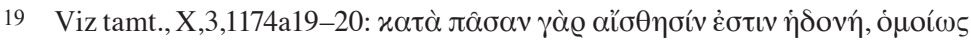

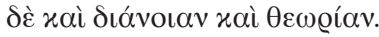

20 Tamt., X,3,1174a23.

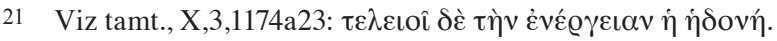

22 Viz tamt., X,3,1173b2-4: Činnost na rozdíl od pohybu nemůže být ani rychlá, ani pomalá; viz také tamt., X,3,1174a14-19: „Také slast je cosi úplného (ö̀ov): není možné nalézt žádný časový úsek trvání slasti, kdy by slast musela vznikat ještě po další čas, aby byla její forma završená.“ Přel. Vojtěch Linka (=VL).

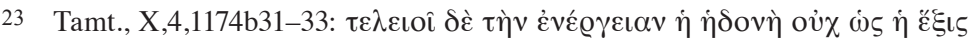

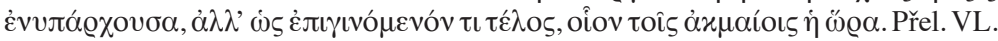

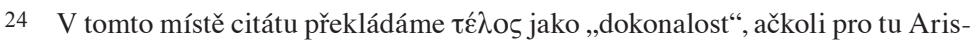

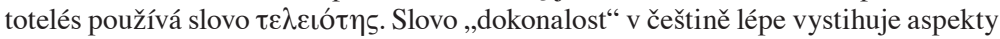

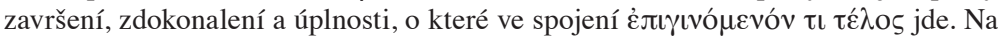
dalších místech ponecháváme $\tau \dot{e} \lambda$ os jako „cíl“.

25 Aristotle, Nicomachean Ethics, přel. Ch. Rowe, kom. S. Brodie, Oxford 2002, str. 436: „A completion/perfection additional to the latter although inseparable from it." 
chu, síly, prestiže atd. Tento půvab (ఝ̋@ $\alpha$, bloom) však není něco, co je k životu nutné, ale co „přináší supervenientní kvalitu našemu životu, dokonalost, které by se jinak nedalo dosáhnout". ${ }^{26}$ Slast tedy činnost završuje a přináší jí něco, co by bez ní činnost neměla. Činnost, kterou doprovází slast, bude její subjekt vykonávat rád, bude toužit po tom, aby trvala nepřetržitě.

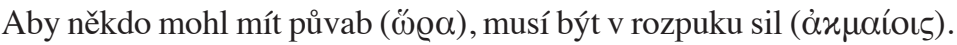
$\mathrm{V}$ př́padě slasti to znamená, že aby slast mohla přistoupit k činnosti, musí tato činnost už splňovat některá kritéria; zejména se musí jednat o činnost, která má cíl sama v sobě a je dovršena v každém okamžiku. Pokud by tomu tak nebylo a jednalo by se např́klad o pohyb, nikoli o činnost, slast by zde nebyla jako přistupující dokonalost. ${ }^{27}$ Stejně tak pokud někdo není v rozpuku sil (tedy nedosahuje své vrcholné životní formy), nepřistoupí k němu půvab stejným způsobem jako k tomu, kdo je.

Pro naše další rozbory je tedy třeba podtrhnout důležitost dvou rysů slasti ve vztahu k činnosti: slast činnost završuje a přináší jí nějakou dokonalost (něco navíc). Aristotelés se nicméně už zde dotýká tématu, které nám umožní přejít k bolesti. Slast a činnost totiž nejsou spojeny nahodile. Naopak, každá činnost má svou vlastní (oixeîa) slast, která ji završuje. ${ }^{28}$ Pokud vykonávám činnost vedení rozhovoru, může být tato činnost završena pouze jí vlastní slastí. Pokud však při této činnosti zaslechnu zvuk píšt'aly, který mi působí větší slast než činnost vedení řečí, není má původní činnost touto slastí završena. Ba naopak, je jí mařena, vždyt' pro zvuk píšt'aly se už nemohu soustředit na vedení řečíi ${ }^{29}$

Tento rušivý rozměr slasti, projevující se při výkonu činností, jimž daná slast není vlastní, nám naznačuje způsob, jakým Aristotelés chápe bolest. Každý zná situaci, kdy pro bolest není schopen soustředit se na činnost, kterou právě vykonává. Tento fenomén Aristotelés uvádí jako př́klad našeho zakoušení bolesti:

„Nebot' slasti vůči činnostem cizí mají téměř stejný účinek jako bolesti jim vlastní: bolesti činnostem vlastní totiž tyto činnosti maří.

26 G. van Riel, Pleasure and the Good Life, str. 57: „,[Pleasure] gives a supervenient quality to our life, a perfection that cannot be reached in any other way."

27 Jednalo by se o slast jako pohyb. I pohyby nám mohou působit slast, Aristotelés by však tuto slast vykládal jako nedokonalou, nebot' by byla spojena s návratem do přirozeného stavu, nikoli s trváním tohoto stavu a dovršenou činností.

28 Viz Aristotelés, Eth. Nic. X,5,1175b17-24.

29 Viz tamt., X,5,1175b3-8. 
Například člověk, pro něhož je psaní a počítání nepř́ijemné a útrpné, psát nebo počítat nebude, a to právě proto, že je to pro něho činnost bolestná. Slasti a bolesti určité činnosti vlastní mají tedy na tuto činnost účinky navzájem opačné. Vlastní jsou však ty, které danou činnost provázejí samu o sobě. Jak bylo řečeno, slasti vůči činnosti cizí způsobují něco podobného jako bolest: činnost totiž maří, byt' nestejným způsobem. ${ }^{\text {“30 }}$

V závěru citátu Aristotelés explicitně formuluje, co bolest způsobuje: bolest maří činnost. Příklad s nevlastní slastí nás zavede pouze tak daleko, že vidíme toto maření jako příčinu toho, že původní činnost nemůže být dovršena slastí. Bolest má tedy na činnost opačný efekt než vlastní slast. Slast činnost završuje, bolest ji maří.

Než postoupíme v našem výkladu dále, předešleme, čím se naše koncepce liší od koncepce Weie Chenga. Cheng také ukazuje, že pro pochopení slasti u Aristotela je nutné vyložit její vztah k činnosti. Dochází $\mathrm{k}$ tomu, že slast $\mathrm{k}$ činnosti přistupuje jako jakési „,vědomí vyššího řádu“ (higher order consciousness). ${ }^{31}$ Pro naše účely stačí poznamenat, že toto vysvětlení vychází z Aristotelovy definice slasti jako „přristupující dokonalosti“ (viz výše). Ve výkladu pojmu bolesti Cheng rovněž probírá možnosti vztahu mezi bolestí a činností. Ve svém rozboru však dochází $\mathrm{k}$ tomu, že primární model pro pochopení bolesti je pohyb, a to sice prudký pohyb, který živočicha vychyluje z přirozeného stavu. ${ }^{32}$ Model bolesti jakožto maření činnosti je podle něho až druhotný a pokrývá pouze velmi specifické prŕíklady bolestí. ${ }^{33}$

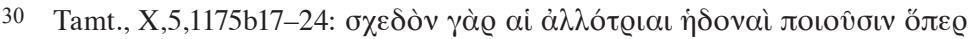

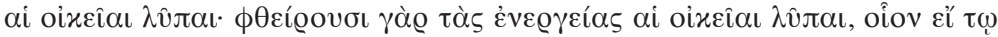

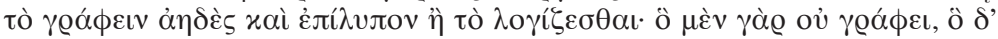

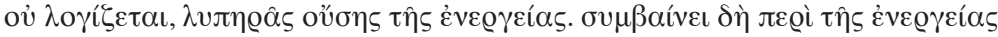

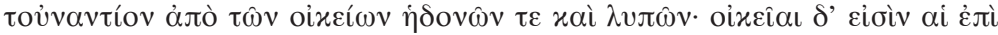

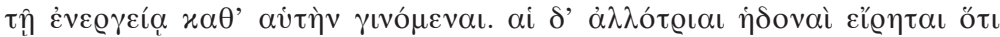

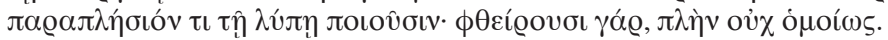

31 Viz W. Cheng, Pleasure and Pain in Context, kapitoly I-VIII.

32 Toto pojetí bolesti jako pohybu odpovídá pojetí bolesti z Platónova Filéba: „Sókr.: Nuže tvrdím, že když se nám harmonie v živocích ruší, že tehdy současně nastává rušení přirozené podstaty a vznik bolesti“ (Philb. 31d). „Sókr.: A dále žízeň je zkáza a strázeň, kdežto účinek tekutiny znova naplňující, co bylo vyschlo, slast a dále nepřirozené rozlučování a rozrušování, totiž stavy nemírné teploty, je strázeň, kdežto naopak osvěžení a ochlazení v souhlase s přirozeností slast" (Philb. 31e-32a).

33 Viz W. Cheng, Pleasure and Pain in Context, str. 366: „Pain should essentially be understood as a particular kinēsis - a pathos of the soul. It is taken to be 
$\mathrm{K}$ upřednostnění pohybu před činností je Cheng veden především ontologickou neslučitelností činnosti a bolesti. Činnost totiž ze své podstaty musí vykazovat jisté rysy, jako je např́ílad dokonalost nebo završenost, které se však neslučují s povahou bolesti. Bolest ze své podstaty dokonalá není, vždyt' narušuje přirozený stav. Ve vztahu k časovosti bolest vykazuje proměnlivost, může být akutní či chronická.

Kromě těchto odlišujících rysů jde také o to, že podle Chenga není vždy možné najít onu činnost, kterou by měla bolest mařit. Tak například pocit'ujeme bolest očí, aniž bychom nutně museli právě vykonávat činnost vidění. Tuto bolest jde však podle něj dobře vysvětlit na základě pohybu, jenž nás vychýlil z přirozeného stavu.

Navzdory těmto Chengovým postřehům se v naší interpretaci Aristotela přikláníme $\mathrm{k}$ tomu, že primárním modelem pro pochopení bolesti je mařená činnost. Kromě pozitivních argumentů pro toto pojetí odpovíme na Chengovy námitky shrnuté v předchozích dvou odstavcích. Naše hlavní motivace je v podstatě podobná jako motivace Chengova, tedy najít jednotný model pro uchopení rozličných fenoménů označovaných Aristotelem jako bolest. Domníváme se však, že vhodnějším nástrojem $\mathrm{k}$ tomu je právě pojem maření činnosti.

\section{Bolest jako maření činnosti v Etice Nikomachově}

Nejprve se zaměříme na problém mařené činnosti, posléze na to, proč tento výměr odpovídá jednotlivým př́kladům bolesti lépe než pojem pohybu.

Vyjděme z definice bolesti jako toho, co maří ( $\phi \theta \varepsilon i ́ @ \varepsilon \imath)$ činnost. Povaha tohoto maření se objasní při dalším rozlišení: „V tom, že také bolest je něco špatného, čemu je třeba se vyhnout, ovšem panuje shoda. Bolest je totiž bud'to špatná prostě a bez dalšího, nebo tím, že něčemu překáží.“34

Předpokládáme takové čtení této pasáže, kdy bolest špatná prostě ( $\dot{\alpha} \lambda \hat{\omega} \varsigma$ $x \alpha x o ́ v)$ je špatná pro každého za všech okolností, kdežto bolest

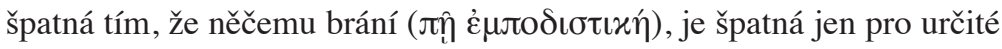

an energeia only in a highly qualified sense, namely as passive reaction to harmful affections within or without.“

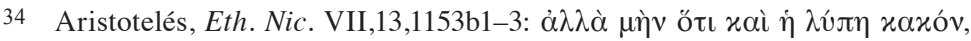

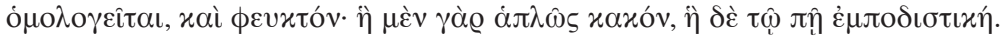


Živočichy za jistých okolností. ${ }^{35} \mathrm{~V}$ dalším výkladu se budeme zabývat zejména druhým typem bolesti, tedy bolestí, která něčemu brání. ${ }^{36}$ Důvod, pro který chápeme bolest něčemu bránící jako primární model pro Aristotelovo chápání bolesti, spočívá v tom, že díky němu můžeme snáze vysvětlit širší spektrum bolestí stejně jako jejich vzájemnou provázanost na různých úrovních života živočicha.

$\mathrm{V}$ běžném životě mluvíme o bolesti nejčastěji ve významu bolesti těla. Je pozoruhodné, že Aristotelés v Etice Nikomachově zmiňuje bolest těla pouze okrajově a soustředí se na fenomény, které bychom dnes nazvali psychickými bolestmi či špatnými náladami. ${ }^{37}$ Přesto se výměr bolesti jako něčeho, co brání činnosti, vztahuje i na tělo. Jakým zpơsobem?

Pokud zakouším bolest v ruce, je bráněno činnosti, kterou má ruka vykonávat, například psaní. Při této činnosti už nezakouším slast, a pokud ano, tak nějak ochuzenou. Bolest v ruce často neskončí ve chvíli, kdy přestanu psát. U mnoha bolestí by bylo těžké najít, co je činností, kterou maří: bolest vnitřních orgánů, bolest pokožky způsobená popáleninou atp. Co je zde mařenou činností? Aby bylo možné použít Aristotelovu teorii bolesti, musí zde nějaká mařená činnost být. Podle naší hypotézy bude touto činností činnost duše. Bude tomu tak zejména proto, že duše a tělo jsou pro Aristotela ve velmi těsném sepětí a prožívání se vždy (snad s výjimkou teoretického myšlení) ${ }^{38}$ týká oduševnělého živého těla, tedy živočicha. ${ }^{39}$

35 Různí lidé budou zakoušet různou bolest v závislosti na svém aktuálním stavu. Pro milovníka matematiky nebude počítání bolestivé, pro jiného člověka ano.

36 Velmi silná akutní bolest je špatná prostě, protože je špatná pro každého živočicha. Zároveň předpokládáme, že je též možné o ní říci, že něčemu brání, pokud se k ní váže to, že znemožňuje vykonávat nějakou činnost. Tento rys u ní nicméně není primární. Tuto bolest chápeme primárně jako prudké vychýlení z přirozeného stavu živočicha. Jednalo by se tedy o výměr bolesti, o kterém mluví Cheng, viz pozn. 33.

37 Aristotelés uvádí např. člověka, který zakouší bolest při psaní a počítání, viz Eth. Nic. X,5,1175b17-24. Bolest těla zmiňuje tamt., X,3,1173b12-13.

38 Aristotelés, De an. I,1,403a8.

39 Vztahu těla a duše u Aristotela, respektive toho, jak se oboje podílí na činnostech, jako je např́íklad smyslové vnímání, se týká široká akademická diskuse mezi M. Burnyeatem, R. Sorabjim, M. Nussbaumovou a dalšími (viz např. M. C. Nussbaum - A. O. Rorty (vyd.), Essays on Aristotle's De Anima, Oxford 1995). V této diskusi jde konkrétně o to, zda a jak dochází při smyslovém vnímání (což je přijímání formy bez látky) k materiálním změnám v těle vnímajícího. Do této diskuse zde nebudeme vstupovat, avšak v obecné otázce vztahu těla a duše se přikláníme ke shrnutí M. Nussbaumové a H. Putnama, podle nichž činnosti vykonávají tělo i duše společně (,,Soul and body are active together"; M. Nussbaum - H. Putnam, Changing 
Pro Aristotelův výměr duše je klíčové konstatování, že pro živé bytosti je duše principem života. ${ }^{40}$ Právě tím se oduševnělá těla liší od neoduševnělých. Být živý znamená minimálně to, že živá bytost sama ze sebe přijímá potravu, roste a zaniká. ${ }^{41}$ Tato minimální kritéria splňují i rostliny, proto i ty jsou živé. Komplexnější živé bytosti, tedy zvîrata, mají další duševní mohutnosti: smyslové vnímání a z něj vycházející schopnost po něčem toužit a něčemu se vyhýbat, což se projevuje místním pohybem a zakoušením slasti a bolesti. ${ }^{42}$ Konečně lidé mohou díky nejvyšší duševní mohutnosti také myslet.

Mohutnosti, které díky duši živé bytosti mají, umožňují žít a jednat, tedy tyto mohutnosti realizovat; subjektem tohoto jednání je živočich, tedy oduševnělé tělo. Duše není schopna většinu svých mohutností vykonávat sama bez těla. ${ }^{43}$ Neměli bychom také zapomínat, že duše je nelátková, nemůže tudíž např́íklad sama sebou pohybovat, jak Aristotelés dokazuje v první knize spisu $O$ duši. Díky duši může ale živočich vykonávat rozličné energeiai - činnosti, např́íklad smyslově vnímat nebo myslet. ${ }^{44}$ Pokud jsme výše předložili hypotézu výměru Aristotelova chápání bolesti jako maření činnosti, chápeme to právě v tom smyslu, že se jedná o maření některé činnosti, kterou živočich díky duši vykonává.

Nemusíme se však omezit pouze na činnosti jako vidění (nebo obecně smyslové vnímání) a myšlení, vždyt' zakoušíme řadu bolestí, v nichž tyto činnosti nejsou mařeny přímo nebo nejsou mařeny vůbec. To lze vysvětlit na úrovni vyživovací duše. Díky ní vykonává živočich rozličné činnosti. To, že se vyživujeme, je totiž projev toho, že nám jde o vlastní

Aristotle's Mind, tamt., str. 45), jedná se tedy o činnost živočicha. Viz také např. Alexandr z Afrodisiady, Alexandri in librum de senso, vyd. P. Wendland, Berlin 1901, 2,16-21: „Je zřejmé, že činnosti (energeiai) oduševnělých [věcí] jsou společné tělu a duši a že všechny vznikají skrze vnímání nebo s vnímáním. Vždyt' vnímání samotné je činnost společná duši a tělu, jak [Aristotelés] jasně ukázal na začátku spisu O vnímání a vnímatelném. Poté podal výměr o vnímavé duši, [a ukázal,] že vnímání je společná činnost duše a těla..."A Aktuální shrnutí daného problému a kompromisní pozici nabízí také K. Thein, Aristotelés o lidské přirozenosti. Od myšlení k anatomii, Praha 2017, str. 142.

40 Aristotelés, De an. II,4,415b13.

41 Tamt., II,1,412a12. Později Aristotelés připojuje další rys: živá bytost plodí sobě podobnou živou bytost, tamt., II,2,414a34.

42 Tamt., II,3,414a32-b16.

43 Tamt., II,1,412b9-413a10.

44 Tamt., II,3,414a32-b16. 


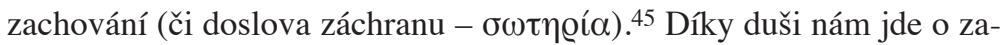
chování vlastní podstaty. Přijímáme a zpracováváme potravu, a proto se vyhýbáme nebezpečí. ${ }^{46}$ Pokud se zraníme, je tato činnost narušena, a třebaže se nemusí jednat o narušení fatální - například při říznutí či spálenině -, oduševnělé tělo, jemuž jde o jeho zachování, je ohroženo,

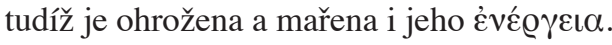

Bolest těla tedy signalizuje, že je zde nějaká překážka, která narušuje celistvost živočicha a která maří činnost vyživovací duše. Popálenina signalizuje, že část živočicha utrpěla nějakou škodu a že následky stále trvají. Proto trvá i bolest. Zatímco u některých bolestí těla je snadné najít konkrétní činnost (pohyb, smyslové vnímání atp.), u jiných je při vysvětlení potřeba sestoupit na rovinu vyživovací duše.

$\mathrm{S}$ bolestmi mařícími činnost vyživovací duše úzce souvisejí bolesti mařící činnost duše smyslové. Při poškození smyslového čidla se stává výkon smyslového vnímání bolestivý. Smyslová duše je zároveň nutnou podmínkou k zakoušení slasti a bolesti. ${ }^{47}$ Pokud by tomu tak nebylo, zakoušely by bolest i rostliny, které mají rovněž vyživovací duši. Živočichové zakoušejí bolest těla ve smyslu maření vyživovací duše díky tomu, že vyživovací duše je komplementární součástí duše živočicha jako takové. Vyživovací a smyslová (u člověka i myslící) duše tvoří jednotu, díky níž může živočich zakoušet maření vyživovací duše. ${ }^{48}$

Na vyšších úrovních života člověka, tedy u činností vykonávaných díky myslící mohutnosti duše, je situace obdobná. I zde bolest maří činnost a brání tomu, aby došla završení. To může probíhat přímo, naprŕíklad člověk, který nemá rád počítání, zakouší útrpnost, když musí

45 Tamt., II,4,416b12-22.

46 Význam tohoto rysu duše shrnuje Ronald Polansky ve svém komentáři k De anima: ,,Saving“ is a most astounding function. To save something is an operation that may involve effort and changes, but is not itself fundamentally a change. After all, to save something is to prevent it from undergoing any major change. ... We may say that saving itself, rather than self-motion, is the best way to characterize life itself. All life as operation of soul is activity in contrast with motion, activity that is always complete and continuable. This activity is not change but saving of the sort of being, of its very life and of the principle of such life. As alive plants save themselves, as do animals and even God. The general way to speak of the operation of what has life is that it saves itself as the sort of living that it is, and the principle of life is a capacity for saving the being and itself." R. Polansky, Aristotle's De Anima, Cambridge 2007, str. 218.

47 Viz např. Aristotelés, De an. II,1,413b20.

48 Ke vztahu zakoušení bolesti a smyslového vnímání viz níže, oddíl 3. 
počítat. ${ }^{49}$ Zároveň je možné i to, že zakoušíme bolest v činnostech spojených s myslící duší (např. při čtení, vedení řečí, učení se), protože zakoušíme nějakou bolest na nižších rovinách duše, tedy vyživovací a smyslové, která přerůstá až do oblasti myslící duše. Bolest zubů brání soustř̌eděnému učení, podobně jako zvuk píšt'aly brání soustředěnému vedení řečí.

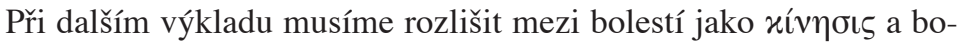
lestí jako mařením évé@ $\gamma \varepsilon ı \alpha$. Viděli jsme v předchozí kapitole, že Aristotelova invence spočívala $\mathrm{v}$ propojení slasti a činnosti. Je však nutné tuto inovaci zavádět i v případě bolesti? Nestačí nám pojetí, které Aristotelés připisuje Platónovi, tedy vychýlení z přirozeného stavu? Domníváme se, že nikoli, a to z následujícího důvodu. Bolest jako vychýlení z přirozeného stavu by vypadala takto: Vlivem poranění ruky jsem (já celkově jako živočich) vychýlen z přirozeného stavu, do něhož se díky uzdravení znovu vrátím. Obtíž spočívá v tom, že aby tato teorie byla koherentní, týkala by se jen omezeného množství př́ípadů, kdy zakoušíme bolest. Aby se jednalo stále o xívๆoıs, šlo by nakonec pouze o př́ípady, kdy nějaký vnější př̀edmět aktuálně působí vychýlení z přirozeného stavu. Pokud dám ruku do ohně, jedná se o tento typ bolesti. Jakmile ale ruku oddálím a už zde není plamen, který by bolest aktuálně působil, jak to, že ji stále zakouším? Od přirozeného stavu už se nijak nevzdaluji a ruka mě stále bolí. Stejně tak by bylo lze argumentovat v celé řadě případů, které Aristotelés definuje jako bolesti, byt' to nejsou bolesti těla, tedy zejména zakoušení útrpnosti při různých činnostech pojících se $\mathrm{k}$ rozumové duši.

$\mathrm{Z}$ tohoto důvodu se přikláníme $\mathrm{k}$ chápání bolesti jako maření غ่vé@ $\gamma \varepsilon ı \alpha$. Na různých rovinách života živočicha zakoušejícího bolest půjde o to nalézt činnost, která je mařena. Například trvající bolest z popáleniny lze snadno interpretovat jako maření činnosti vyživovací duše, tedy narušení integrity těla. Bolest po poranění oka nebo jiného smyslového orgánu pak bude bránit i činnosti smyslové duše a bolest z počítání

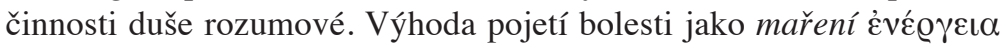
tedy spočívá v tom, že dokáže pojmout širší spektrum bolestí.

Model bolesti jako maření ع̇vé@ $\gamma \varepsilon ı \alpha$ lze snadno aplikovat na příklady bolestí uváděné Aristotelem v VII. a X. knize Etiky Nikomachovy. Bolestem těla věnuje Aristotelés pouze jednu zmínku: člověk zakouší bolest, když je řezán. ${ }^{50}$ To, jakým způsobem se bolesti těla dají chápat

49 Viz Aristotelés, Eth. Nic. X,5,1175b17-24.

50 Viz tamt., X,3,1173b12-13. 
jako maření činnosti vyživovací duše, bylo již nastíněno výše. Na tomto místě můžeme doplnit následující: pokud se říznu do končetiny, může být bolest tak intenzivní, že mi zabrání vykonávat skrze končetinu její funkci. Ale i v případě, že říznutí není tak vážné a končetinu používat mohu, dochází k narušení funkce organismu jako celku, a tím pádem i duše, která se o organismus stará a pro kterou je tělo nástrojem jejích jednotlivých činností. ${ }^{51}$ Bolest těla zakoušíme právě proto, že došlo k narušení naší psychofyzické jednoty. ${ }^{52}$

Aristotelés však věnuje více místa bolestem jiného druhu, jako například v následujícím citátu:

„Bolesti činnostem vlastní totiž tyto činnosti maří. Například člověk, pro něhož je psaní a počítání nepř́ijemné a útrpné, psát nebo počítat nebude, a to právě proto, že je to pro něho činnost bolestná.“53

Při psaní a počítání se realizuje myslící úroveň duše. Pokud však člověku z jakéhokoli důvodu tyto činnosti nepůsobí slast, nemá je rád, jsou mu nepř́ijemné, tak při jejich realizaci bude zakoušet bolest. Důsledkem zakoušení této bolesti bude ovšem to, že člověk bud' bude psát a počítat dál, aniž by ovšem z této činnosti pocit'oval slast, anebo s touto činností úplně přestane, bolest ji tedy úplně zmaří. Zde je jasně vidět, že bolest

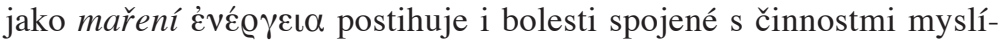
cí úrovně duše. Pokud bychom se z našeho moderního, byt' vzhledem $\mathrm{k}$ Aristotelovi anachronického pohledu přidrželi dělení na bolesti těla a bolesti duše, je možné říci, že Aristotelova teorie postihuje obě kategorie. A v případě pojetí jednoty těla a duše, jak ji pojímá Aristotelés, je tento model taktéž aplikovatelný, a to at' už bolest probíhá na jakékoli rovině duše s větším (jako u řezání) či menším (jako u počítání) vztahem k tělu.

Vyjdeme-li nad rámec textu, nabízí se otázka, zda lze Aristotelovu teorii aplikovat i na typy bolestí, které on sám (alespoň podle dochovaných textů) nezkoumal. Tím máme na mysli např́íklad chronickou bolest, jejíž

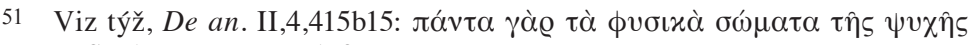
óg $\gamma \alpha v \alpha$. Souhrnně tamt., II,1-2.

52 Zároveň musíme mít na zřeteli to, že díky hierarchii jednotlivých úrovní duše bude silná bolest jakožto maření vyživovací duše nepřímo bránit i vyšším činnostem živočicha, tedy u zvíŕat například vnímání a pohybu, u člověka myšlení.

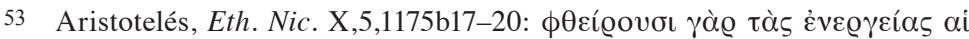

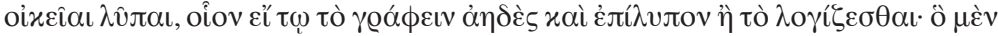

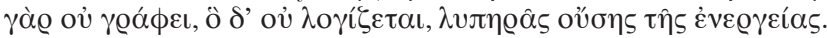


analýze se věnuje řada současných teorií, byt' se značnými obtížemi. ${ }^{54}$ Chronická bolest snad ještě více vybočuje z modelu vzdalování se od přirozeného stavu, nebot' vzhledem ke svému nepřetržitému trvání nejde o nějaký pohyb od přirozenosti (její hladina také bývá, byt' ne vždy, poměrně stálá). Je ovšem nějaká činnost, kterou tato bolest maří? Trvá-li bolest stále, musí stále probíhat také činnost, kterou bolest ovlivňuje. Na bazální rovině by touto činností mohly být právě činnosti smyslové duše, které ze své definice musí probíhat stále. Aristotelés klade podmínku přítomnosti smyslové duše, aby živočich mohl vnímat bolest. Je ale smyslová duše činná i ve spánku? Aristotelés tvrdí, že je možné, aby během spánku docházelo ke smyslovému vnímání, byt' v jiném smyslu než v bdělém stavu. Toto vnímání musí být velmi oslabené vzhledem k tomu, že smyslem spánku je, aby si smyslová a myslící duše odpočinuly, a mohly pak během bdění vykonávat své funkce. ${ }^{55}$ Chronická bolest tak může trvat stále, resp. tak dlouho, dokud je narušena činnost smyslové duše. 56

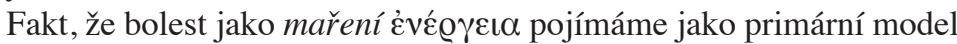
v Aristotelově teorii bolesti, by neměl zastínit to, že bolest pojatá jako

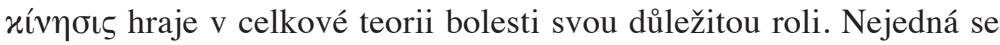
vposledku o dvě zcela oddělená chápání: pokud jsem vychýlen z přirozeného stavu, je jasné, že je zároveň narušena činnost nějaké části mé duše. Bolest jako maření ėvé@ $\gamma \varepsilon\llcorner\alpha$ je tedy primární model pro chápání bolesti pro svůj široký záběr. Zároveň se ukazuje, že je-li narušení činnosti duše popsáno jako vychýlení z přirozeného stavu, Aristotelova teorie není od pojetí, které Aristotelés připisuje Platónovi, tak vzdálená, jak by se mohlo zdát. Avšak díky tomu, že Aristotelés zavedl pojem činnosti, může popsat bolest, aniž by byl vázán konceptem ,pohybu“ nebo „pocit'ovaného vznikání““.

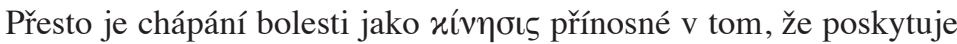
cenné vhledy do problematiky zakoušení bolesti a vztahu bolesti a smyslového vnímání, kterým se budeme věnovat v následující kapitole.

54 Viz M. Aydede, Pain, in: E. N. Zalta (vyd.), The Stanford Encyclopedia of Philosophy, vyd. E. N. Zalta, Spring 2019 Edition, dostupné on-line: https://plato. stanford.edu/archives/spr2019/entries/pain. Navštíveno 30. 4. 2020.

55 Viz Aristotelés, De insomn. 459b1, a De somn. vig. 455b25.

56 Zde je pozoruhodné, že bolest má širší pole působnosti než slast, nebot' slast se váže na činnosti, které nemohou trvat neustále z důvodu křehkosti těla živočicha, resp. z toho důvodu, že živočich se po čase unaví a nemůže už vykonávat činnost, která mu působila slast. Naproti tomu činnost, kterou maří chronická bolest, neustane nikdy. 


\section{Bolest a smyslové vnímání}

Zakoušení bolesti bývá v současné filosofii často interpretováno jako fenomén spadající pod smyslové vnímání ${ }^{57}$ Aristotelés oba fenomény odděluje, byt' mezi nimi stanovuje vztah, jehož analýza dále zpřesní výměr bolesti a jejího zakoušení. V pojednání $O$ duši čteme:

„Smyslové vnímání je podobné pouhému vyslovení a myšlení. Pokud se vyskytne něco slastného nebo bolestivého, tak to [smyslové vnímání] následuje nebo od toho prchá skrze přitakání nebo odmítnutí. Zakoušení slasti nebo bolesti spočívá v činnosti vnímavého ústředí vzhledem k dobré nebo zlé věci jako takovým. A co do [svého] uskutečnění jsou útěk a touha totéž, přičemž schopnost toužit a schopnost utíkat se navzájem neliší, ani se žádné z nich neliší od toho, co je schopno smyslového vnímání. Liší se však co do svého bytí. “58

Situace, o které se zde mluví, bývá rozebírána na př́kladu ovce, která vidí vlka. ${ }^{59}$ Ovce je díky vjemu vlka instinktivně vedena $\mathrm{k}$ tomu, aby od něj utekla. Pokud by ovšem viděla pastvinu, bude touhou vedena $\mathrm{k}$ tomu, aby se k ní přiblížila. Smyslové vnímání zde působí jako zprostředkovatel vztahu mezi subjektem a dobrým nebo zlým - slastným nebo bolestivým - objektem. To, že se živočich vztahuje k některým objektům jako k dobrým a k některým jako ke zlým, je závislé na třech faktorech. Jde o to, jaký je přirozený stav (fysis) živočicha, jaký je jeho aktuální stav a do jakého stavu ho pohne daný objekt. Ovce před vlkem uteče, protože zakouší, že by ji (v tomto případě fatálně) odvedl od jejího přirozeného stavu. Stejně tak pokud máme žízeň, působí nám nápoj slast, nebot' nás z našeho aktuálního stavu žízně dovádí do přirozeného stavu napojenosti.

57 Pro úvod do diskuse o bolesti v současné analytické filosofii mysli viz M. Aydede, s. v. Pain.

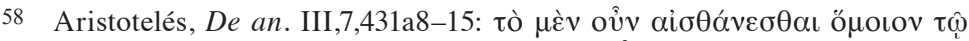

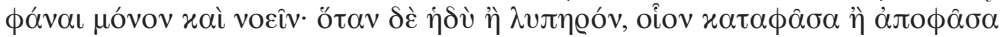

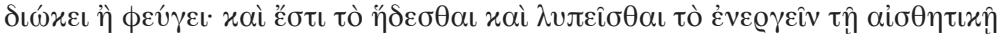

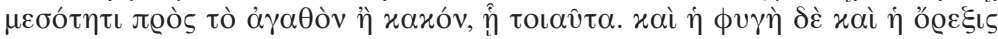

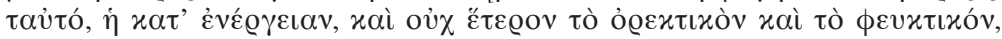

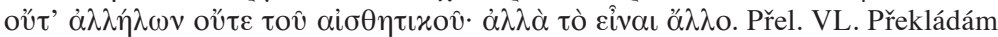

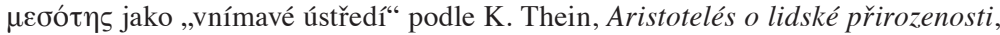
str. 138.

59 Následující interpretace se opírá o knihu K. Corcilius, Streben und Bewegen. Aristoteles' Theorie der animalischen Ortsbewegung, Berlin 2008, zejm. str. 80 nn. 
$\mathrm{V}$ případě bolesti jde o to, že pokud zakoušíme předmět, který nás odvádí od našeho přirozeného stavu, budeme od něj chtít utéct. Tak je tomu například, pokud se k nám přibližuje plamen. Oddálíme ruku dříve, než dojde k popálení, nebo bezprostředně poté, co se spálíme. Tím pádem lze říci, že výše citovaná pasáž mluví o dvou typech bolesti (a slasti). Jednak půjde o bolest předjímanou (ovce - vlk), jednak o aktuální bolesti těla. V obou případech se jedná o to, že bolest živočicha vzdaluje od jeho při-

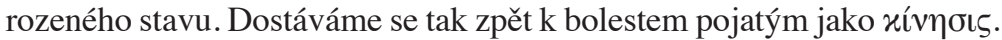

Podstatné je zde ovšem to, že nám Aristotelés říká o bolestech typu

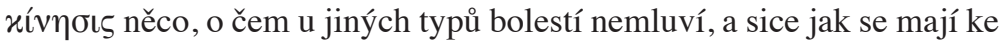
smyslovému vnímání. Klíčové je, že aby ovce utekla před vlkem, musí ho vidět (nebo nějak jinak smyslově vnímat). Pouze tehdy se spustí mechanismus vztahu aktuálního stavu, přirozeného stavu a objektu. Sama bolest, kterou živočich předjímá nebo aktuálně zakouší, není ovšem se smyslovým vnímáním totožná; vztah smyslového vnímání a zakoušení bolesti bychom mohli charakterizovat jako jeden akt, ale dvojí bytí. Smyslové vnímání umožňuje to, že živočich může zhodnotit (nikoli ovšem ve smyslu rozumové úvahy), zda mu daný objekt přinese či přináší slast či bolest. Bolest typu xívๆoıৎ zakoušíme tedy díky zprostředkování smyslovým vnímáním jako předjímané či aktuální oddálení od prirozeného stavu.

\section{Zakoušení bolesti typu maření દ̇vé@ $\gamma \varepsilon\llcorner\alpha$}

U bolesti jako maření činnosti, kterou jsme vymezili výše, není možné uvést přímý Aristotelův text, který by podal výměr zakoušení této bolesti. Musíme tedy vyjít z rozboru slasti. Pokud slast zakoušíme jako završení a dokonalost činnosti, bude bolest zřejmě jakési strukturální narušení činnosti. Je však třeba říci, že toto narušení nebude něčím, co

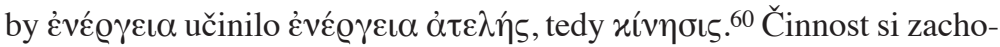
vá, pokud není zcela zmařena, to, že má cíl sama v sobě, bude jí však scházet završení a bude ochuzena o celé spektrum benefitů, které přináší přistupujicí dokonalost, tedy slast. Zejména bude činnosti spojené s bolestí chybět onen rozměr soustředění a pohlcení tím, co činíme. Pokud nás něco bolí, bude i činnost, kterou si obvykle užíváme, zbavena své lákavosti a místo na ni se budeme soustředit na bolest.

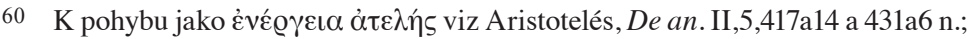
Phys. III,1,1201b31-33; Met. IX,3,1047a30-1047b1. 
$\mathrm{V}$ případě bolestí těla je situace o to zajímavější a vážnější, že zde bolest působí na mnoha různých rovinách života živočicha. Silná bolest zubů nás samozřejmě také ovlivňuje na rovině myslící duše tak, že se nemůžeme soustředit na čtení knihy, primárně ji ovšem zakoušíme na rovině vyživovací a smyslové duše.

Důsledky maření činnosti se naplno vyjeví u živočichů, kteří zakoušejí dlouhotrvající bolest. Omezíme-li se na člověka, tedy na bytost obdařenou také myslící duší, musíme konstatovat, že dlouhodobé maření činnosti duše člověka v podobě bolesti vede $\mathrm{k}$ dlouhodobé deprivaci slasti. To má ovšem zásadní důsledky pro život živočicha, nebot' cílem lidského života je blaženost doprovázená slastí. ${ }^{61}$

Zakoušení bolesti je tedy možné obecně pochopit jako narušení struktury organismu, a to jednak ve významu narušení struktury činnosti, jednak ve významu narušení struktury jakožto vychýlení z přirozeného stavu. Zakoušení narušení struktury organismu je jasnější u bolesti typu

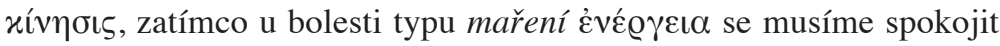
s výměry typu maření soustředění, útrpnost, deprivace slasti apod.

\section{Závěr}

V tomto článku jsme se snažili ukázat, že Aristotelés nabízí komplexní teorii bolesti, byt' je pro nedostatek textové evidence třeba ji rekonstruovat. Klíčovým bodem v této rekonstrukci je vztah bolesti a činnosti a vliv, který bolest na činnost má. Ukázali jsme, že bolest působí opačně než slast. Bolest maří činnost. Toto maření se projevuje rušením soustředění, mařením výkonu činnosti. Pokud zakoušíme nějakou bolest, měli bychom se ptát, jakou činnost bolest maří a proč tomu tak je. Aristotelovo chápání bolesti je komplexní natolik, že nabízí vysvětlení celé škály typů bolesti, at' už to jsou bolesti akutní nebo chronické, bolesti těla nebo bolesti duše. Stejně tak jako v teorii slasti i zde je klíčové použití

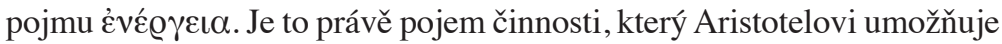
vysvětlit tak mnohostranný fenomén, jako je bolest.

Tím, že je živé tělo z podstaty oduševnělé, což znamená, že tělo jako celek i jeho jednotlivé části mohou vykonávat jisté funkce, je každá bolest vždy záležitostí jak těla, tak duše. Pokud mluvíme o živém tělu živočicha, rozlišení na tělo a duši není vlastně dále udržitelné, pokud bychom jimi mínili dvě složky, jež mohou fungovat na sobě nezávisle.

61 Aristotelés, Eth. Nic. I,7,1098a12-18. 
Tělo živočicha je vždy oduševnělé tělo. Bolest, kterou živočich zakouší, se tedy týká živočicha jako celku. Pouze při hlubší analýze můžeme dále odstiňovat, zasahuje-li bolest více duši jakožto princip života a jeho funkcí, nebo tělo jako to, čím jsou tyto funkce vykonávány. Vždy ale bude zasahovat jak tělo, tak duši. Pokud tedy chápeme bolest jako maření činnosti duše, chceme tím pouze zdůraznit perspektivu, kdy bolest zasahuje duši jakožto původce a prríčinu činností, které vykonává živočich - oduševnělé tělo. Tato perspektiva nám totiž o bolesti a jejím zakoušení živočichem může říci více, než kdybychom se soustředili pouze na perspektivu těla. Zejména pojem činnosti je zde důležitý, a to pro své spojení s problémem dobrého lidského života a blaženosti.

Je však třeba přiznat, že výměr zakoušení bolesti jako zakoušení narušení struktury činnosti otevírá další otázky. U dlouhotrvajících bolestí totiž může nastat situace, kdy člověk ,zapomene“, že ho něco bolí, a není si aktuálně své bolesti vědom. Když si pak svou bolest znovu uvědomí, lze předpokládat, že i v době, kdy si jí nebyl bezprostředně vědom, na něj nějak působila. Aristotelova teorie zde, tedy v otázce bolestí, které aktuálně nevnímáme, nabízí zajímavý model narušené činnosti, kdy není nutné, aby toto narušení bylo zakoušeno. O to více by ale bylo třeba rozpracovat přesnou podobu narušení struktury činnosti. Zejména tato otázka, vyžadující další výzkum, je zajímavá i vzhledem k Aristotelově filosofii obecně, nebot' se dotýká ústředního pojmu (na-

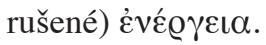

Předložená teorie zakoušení bolesti podle Aristotela má být tedy zároveň podnětem $\mathrm{k}$ dalšímu bádání a rozvíjení témat, o kterých zde bylo pojednáno. Aristotelova teorie bolesti je velmi komplexní a snaží se pojmout všechny typy bolesti. Neomezuje se pouze na bolesti těla a zároveň se snaží vyrovnat s otázkou vztahu zakoušení bolesti a smyslového vnímání. Tím se zde otevírá prostor konfrontovat Aristotelovo pojetí bolesti se současnými teoriemi, a přispět tak k hlubšímu pochopení tohoto, pro lidský život klíčového, fenoménu. ${ }^{62}$

62 Tento text vznikl v rámci zastř̌ešujícího projektu Krize racionality a moderní myšlení jako výsledek projektu „Vydání článku vycházejícího z diplomové práce v odborném periodiku (Diplomová práce: Pocitování bolesti podle Aristotela, obhajoba v červnu 2019)“ řě̌eného na Filozofické fakultě Univerzity Karlovy z prostř̌edků Specifického vysokoškolského výzkumu na rok 2019. 


\section{ZUSAMMENFASSUNG}

Der vorliegende Beitrag untersucht die Problematik des Schmerzes in Aristoteles' Philosophie und die Art und Weise, wie die Tiere Schmerz erfahren. Der Schmerz und die ihm entgegengesetzte Lust spielen eine wichtige Roll in Aristoteles' Ethik. Dies liegt hauptsächlich an der engen Verbindung zwischen Lust und Wirklichkeit (energeia). Aristoteles argumentiert, dass die Lust die Wirklichkeit als ihre nachträgliche Vervollkommnung perfektioniert. Der Artikel versucht zu zeigen, dass wir zum Verständnis des Schmerzbegriffs bei Aristoteles auch das Verhältnis von Schmerz und energeia als solches in Betracht ziehen müssen. Obwohl einige Schmerzen als kineseis klassifiziert werden können, die das Tier aus seinem natürlichen Zustand bringt, argumentiert der Artikel, dass Schmerzen auch als Beeinträchtigung der energeia verstanden werden können. Während die Lust die energeia vervollkommnet, verhindert der Schmerz ihre Vervollkommnung. Der Beitrag zeigt, welche Konsequenzen dieser Schmerzbegriff als Verhinderung für das Tierleben bedeutet und wie er sich auf einige andere wichtige Bereiche der Philosophie von Aristoteles, wie Sinneswahrnehmung und Psychologie, bezieht. Dank seiner umfassenden Theorie der Seele kann Aristoteles Schmerzen sowohl bei Tieren als auch bei Menschen erläutern und eine Theorie der körperlichen und psychischen Schmerzen vorlegen. Schließlich argumentiert der Beitrag dafür, dass die Erforschung des Schmerzbegriffs bei Aristoteles nicht nur zu einem besseren Verständnis des Schmerzbegriffs im Allgemeinen beitragen kann, sondern auch zu einem besseren Verständnis einiger komplizierten Teile der aristotelischen Philosophie, insbesondere seiner Theorie der energeia.

\section{SUMMARY}

The article explores the question of pain in Aristotle's philosophy and the way animals experience pain. Pain and its opposite pleasure play an important role in Aristotle's ethics. This is mainly because of the close connection between pleasure and actuality (energeia). Aristotle argues that pleasure perfects the actuality as a supervenient perfection. The article tries to show that in order to understand the notion of pain in Aristotle, we must also comprehend the relation between pain and energeia. Even though some pains can be classified as kineseis, moving the animal out of his natural state, the article argues that pain can also be understood 
as distorting the energeia. Whereas pleasure perfects the energeia, pain hiders its perfection. The article shows what this notion of pain as hindrance means for animal life and how it relates to some other important areas of Aristotle's philosophy, such as sense-perception and psychology. Thanks to his broad theory of the soul, Aristotle can explain pain in both animals and human beings and provide a theory for both bodily and psychical pain. Finally, the article argues that exploring Aristotle's notion of pain can contribute not only to a better understanding of the notion of pain generally but also of some intricate parts of Aristotle's philosophy, especially his theory of energeia. 